\title{
Antioxidant Capacity Comparison of Ethanolic Extract of Soursop (Annona muricata Linn.) Leaves and Seeds as Cancer Prevention Candidate
}

\author{
Dyah Ayu Widyastuti', Praptining Rahayu ${ }^{2}$ \\ 1,2Biological Education, FPMIPATI Universitas PGRI Semarang, \\ Jl. Lontar No. 1 Phone (024) 8316377 Semarang 50125 \\ Author correspondency: \\ wid.dyah@gmail.com ${ }^{1}$; ningbiologi@gmail.com²
}

\begin{abstract}
Annona muricata Linn. (soursop) is one of tropical plants which have relatively complete chemical compounds. It has flavonoid, tannin, phytosterol, alkaloid, etc. The high antioxidant compound in soursop is believed as cancer prevention so the cancer threat in the world can be minimized. The antioxidant compound in soursop can be found not only in its fruit, but also in other parts like leaves, seeds, etc. Based on that potency, this study aimed to compare antioxidant capacity of soursop leaves and seeds, also to study about the utilization of soursop parts which is usually not used. This research began with maceration to extract leaves and seeds with $96 \%$ ethanol. Ethanolic extract of soursop leaves and seeds were then tested for antioxidant capacity with DPPH (1,1-diphenyl-2-picrylhydrazyl) method. The result showed that antioxidant capacity of soursop leaves and seeds are 85,66875\% and 39,0166, respectively. The antioxidant capacity of leaves is higher than seeds due to seed's extraction difficulty so its antioxidant compound could not be extracted optimally. However, either leaves or seeds extract in this study are potential as antioxidant resources because there are no significant differences between antioxidant capacity of both extract.
\end{abstract}

Keywords: Annona muricata Linn.; Antioxidant capacity; DPPH; extraction.

\section{INTRODUCTION}

Cancer is the most dangerous killer in the world nowadays. Lung cancer cause 1,3 millions of death a year, stomach cancer take the second place with 803 thousands of death a year, then colorectal cancer with 639 thousands of death a year, and breast cancer with 519 thousands of death a year. More than $70 \%$ death number were happen in developing countries with low health facilities (WHO, 2009).

Cancer can be triggered by accumulation of free radicals compounds. Actually, our body needs free radicals in normal amount to prevent inflammation, kill pathogen microbes, and restrain blood vessel's smooth muscle. The problem is free radicals will be carsinogen in large amount so it can trigger the growth of cancer cells. Due to its importance, we need antioxidant to regulate the existence of free radicals inside our body, so its amount can be arranged (Limbono, 2013).

Antioxidant can play a role to supply hydrogen radicals and as free radicals acceptor so its postpone initiation of free radicals forming (Puspitasari et al., 2016). Antioxidant can be obtained either natural or artificial. Synthetic antioxidant are highly effective but does not safe enough to be consumed. Based on that fact, the synthetic antioxidant utilizing has to be checked.
Natural antioxidant has better effect than artificial one. These antioxidant can naturally obtained by consuming fruits and vegetables because both of them contain natural antioxidative effect due to vitamin $\mathrm{C}, \mathrm{E}$, betacaroten, and other polyphenolic substances (Nihlati et al., 2014).

Based on research by Puspitasari et al. (2016), one of the most valuable fruits which regularly extracted as natural supplement is soursop (Annona muricata Linn.). It has known that soursop has flavonoid, tannin, phytosterol, and alkaloid which can be play a role as an antioxidant. Regularly, soursop consumption limited on its fruit. People only consume the water extract of soursop as cancer prevention. On the other hand, the utilization of leaves and seeds extract of soursop has not been studied yet. Both of them has to be compared to determine which one has higher antioxidant capacity.

The objective of this research is to find either leaves or seeds of sousop (A. muricata Linn.) which has higher antioxidant capacity when extracted with ethanol. So, the utilization of soursop (A. muricata Linn.) will be more appropriate.

\section{MATERIALS AND METHODS}

This research needs soursop (A. muricata Linn.) leaves and seeds, 96\% ethanol, HCl, DPPH (1,1-diphenil-2- 
picrylhydrazyl), aquades, $\mathrm{H}_{2} \mathrm{SO}_{4}, \mathrm{NaOH}$, mortar and pestle, grinder, rotary evaporator, glassware, analytical balance, sentrifuge, and UV-Vis Spectrophotometer.

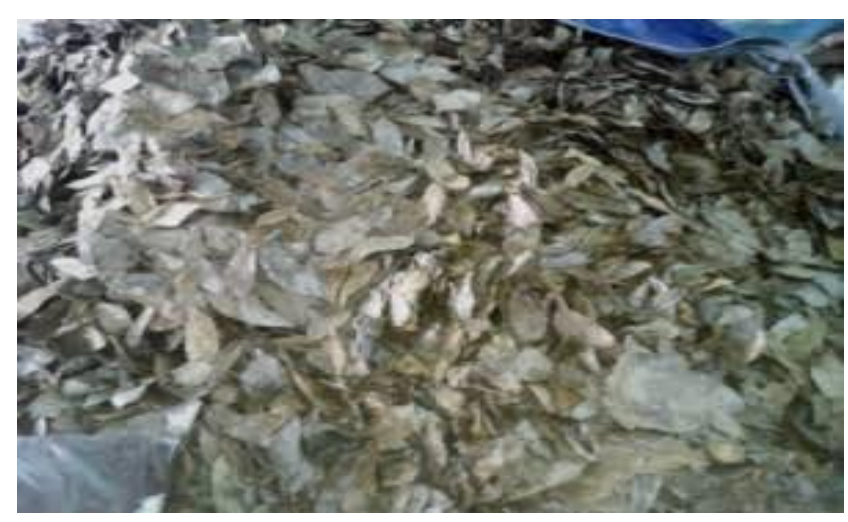

Figure 1. Soursop (A. muricata Linn.) leaves.

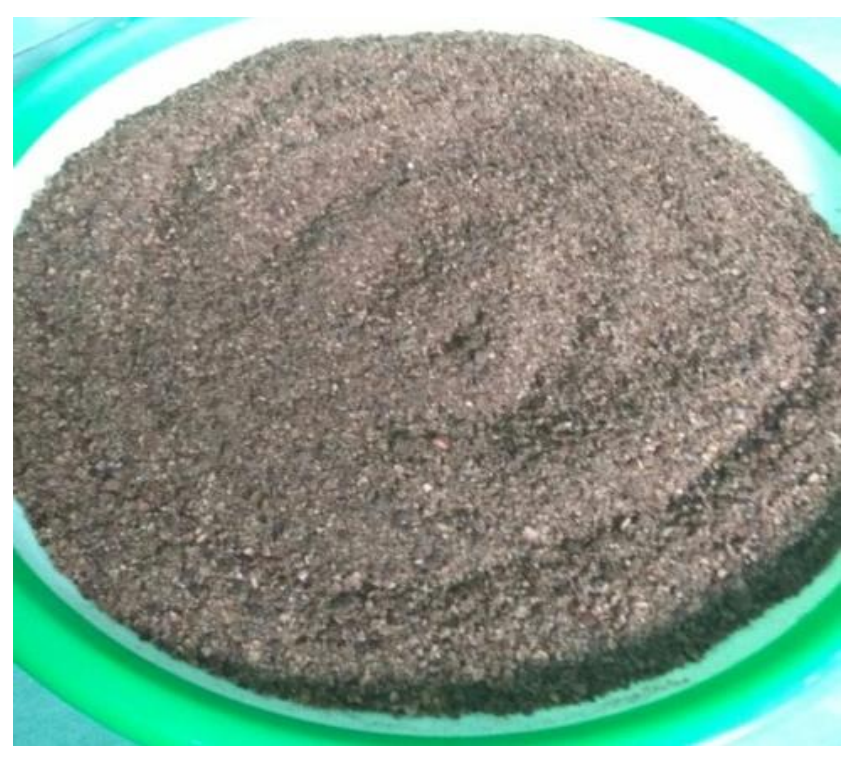

Figure 2. Soursop (A. muricata Linn.) seeds.

The dried leaves (Figure 1) and seeds (Figure 2) were extracted with $96 \%$ ethanol by maceration of each $800 \mathrm{gr}$ of leaves and seeds. The whole filtrate was concentrated with rotary evaporator until $1 / 3$ volume remain. The ethanol residues was then be evaporated until concentrated extract was formed with constant weight. The antioxidant capacity of leaves and seeds extract were then measured by DPPH test.

Samples were divide into two groups, leaves extract (L) and seeds extract (S). Twenty five $\mathrm{mg}$ leaves (L) and seeds (S) extract was measure then dissolved to $25 \mathrm{ml}$ ethanol (stock solution). Both $\mathrm{L}$ and $\mathrm{S}$ stock solution were pipetted $0,1 \mathrm{ml} ; 0,2 \mathrm{ml} ; 0,3 \mathrm{ml}$; and $0,4 \mathrm{ml}$. So the concentration was 4 ppm; 8 ppm; 12 ppm; and 16 ppm, respectively. Five $\mathrm{ml}$ of $0,5 \mathrm{mM}$ DPPH was added to each solution then its volume was adjusted. The standard solution was made by added $25 \mathrm{ml}$ ethanol to $0,5 \mathrm{mM}$ DPPH.

The DPPH absorbance was measure with UV-Vis spectrophotometer in $515 \mathrm{~nm}$ wavelength. Antioxidant capacity was measured as decreasing of DPPH absorbance due to sample addition. The mean of both leaves (L) and seeds (S) antioxidant capacity were then calculated. Analysis using non-parametric of two independent samples of Mann-Whitney test with $\alpha 0,05$ were done to know the antioxidant capacity of each extract.

\section{RESULTS AND DISCUSSION}

The result of this research showed that antioxidant capacity of soursop (A. muricata Linn.) leaves (L) and seeds (S) of ethanolic extract by DPPH test have different level. Leaves (L) extract showed higher antioxidant capacity than seeds (S) extract (Table 1 ).

Based on the Table 1, the antioxidant capacity of soursop leaves (L) ethanolic extract is $85,67 \%$. On the other hand, the antioxidant capacity of soursop seeds (S) ethanolic extract is only $39.01 \%$. The antioxidant capacity play an important role as health protector. This capacity will prevent free radicals so its side effect can be minimalized (Shekhar and Anju, 2014). Due to the advantage, the higher antioxidant capacity will improve the samples potency to be used as protector for some common free radical threat. Those result showed that soursop leaves (L) of ethanolic extract has higher potential to obstruct side effect of free radicals as one of cancer growth trigger compared with seeds (S) extract. Antioxidant capacity of soursop leaves (L) and seeds (S) ethanolic extract were proved that both of them have ability to decrease the risk of chronic diseases caused by free radicals, include cancer and heart attack.

Table 1. Antioxidant capacity of soursop leaves (L) and seeds (S) ethanolic extract with DPPH test.

\begin{tabular}{lll}
\hline No. & Samples & Antioxidant Capacity $(\%)$ \\
\hline 1. & $\mathrm{~L}_{1}$ & 85,99 \\
2. & $\mathrm{L}_{2}$ & 85,35 \\
& Leaves Extract & $\mathbf{8 5 . 6 7}$ \\
3. & $\mathrm{S}_{1}$ & 39,18 \\
4. & $\mathrm{S}_{2}$ & 38,85 \\
& Seeds Extract & $\mathbf{3 9 . 0 1}$ \\
\hline
\end{tabular}

The common antioxidant sources are vitamin $\mathrm{C}$, vitamin $\mathrm{E}$, carotene, and phenolic acid which can be find inside seeds, fruits, and vegetables (Shekhar and Anju, 2014). Those facts strengthen the result of this study 
which said that either soursop leaves (L) or seeds (S) ethanolic extract have potential factor to be an antioxidant sources naturally.

Soursop (A. muricata Linn.) has high vitamin C and polyphenolic compound. Phenol and flavonoid which contained in soursop also play a significant role as antioxidant due to molecular structure which give its electron to free radicals molecules. The higher level of phenol and flavonoid compound, the higher antioxidant capacity it have (Prasetyorini et al., 2014).

Reactive Oxygen Species (ROS) and Reactive Nitrogen Species (NOS) are free radicals which are formed by either metabolic pathway or external resources. Actually, free radical is important substance for energy sources, detoxification, chemical signal, and immunity function. But, the excessive production of free radicals cause biomolecule damage inside cell (such as DNA, lipid, protein, carbohydrate), instead of protect them (Akomolafe \& Ajayi, 2015). Free radical is also frequency associated with oxidative reaction inside the food and biological system which cause oxidative damage and trigger some human disease, such as neural degeneration, diabetes, and some type of cancer.

The danger of free radical discussed above trigger higher research of antioxidant resources which can be an alternative prevention of oxidative damage. Chew et al. (2011) said that there are many plant species with bioactive compound which potential as antioxidant resources, including soursop (A. muricata Linn.). Almost all parts of soursop plant have potency as antioxidant sources although each part has different capacity level. This days, antioxidant capacity of soursop plant often reported to be used as potential anticancer compound.

Nowadays, usage of soursop plant still limited on its leaves. Whereas, antioxidant compound is also find in other parts of soursop plant, such as seeds which not exploited yet. To know about its antioxidant capacity, it can be measured by DPPH (diphenylpycryl-hydrazyl) test. Extraction process has to be done before DPPH test proceed. In pharmaceutical field, extraction use to prepare natural medicine by separate active compound from plant tissues use selective solution and persistent standard procedures. Ethanol was used in this research to extract soursop leaves (L) and seeds (S). Ethanol is common solvent use at extraction due to its safety. Ethanol has characteristic as polar solution so it can solve with water.

In this research, maceration was used as extraction method. Maceration is extraction process use solution with repeated mixture at room temperature. Maceration was used due to its simple process and not time consuming. Ninety six persen ethanol was used, so the evaporation of ethanol residue can be faster. After maceration process, the leaves and seeds extract was then measured with DPPH test to know about its antioxidant capacity.
DPPH (1,1-diphenil-2-picrylhydrazyl) is a method that quick, simple, and sensitive to measure antioxidant capacity. It only needs a little sample so we do not have to prepare sample in a large amount. Principal characteristic of this test is to measured antioxidant capacity by analyze the changes of DPPH color intensity. DPPH as free radical have free electron which visualize violet gradation colour. The violet colour change to yellow when the electron paired. Decreasing of free radical charges will change the intensity of violet colour. The changes caused by reaction between DPPH crystal molecules with hydrogen which release from soursop leaves and seeds ethanolic extract chemical compound. That bond form 2,2-dyphenyl-1picrylhydrazine and cause colour changes from violet to yellow (Fathurrachman, 2014).

Based on the result of this study, leaves (L) extract has higher antioxidant capacity than seeds extract, that is $85,67 \%$ and $39,01 \%$, respectively. The leaves (L) extract antioxidant capacity affirm the result of another research by Putri (2012) which conclude that $500 \mu \mathrm{g} / \mathrm{ml}$ soursop leaves ethanolic extract showed antioxidant capacity to free radical such as 1,1-diphenyl-2-picrylhydrazyl in the amount of $88,77 \%$. High level of antioxidant capacity which showed by soursop leaves (L) ethanolic extract may potentially be used as natural product for cancer prevention.

Lower antioxidant capacity on soursop seeds (S) ethanolic extract was caused by its difficult extraction compare with leaves extraction. Soursop seeds contain alkaloid compound that is acetogenin and annonaine (Idrus et al., 2012). Those compounds mention before have potential character as antioxidant. Yet, the seeds antioxidant capacity lower than leaves due to its difficult handling and extraction. The extraction difficulties was caused by its hard and rough structure with unbreakable outer layer.

Acetogenin of soursop seeds (Annonaceous acetogenin) has to be examined and proved its characteristic as anticancer, antiparasite, insecticide, antiworm, antibiotic, and antivirus (Arifianti et al., 2014). That acetogenin play a role as barrier and killer to cancer cells selectively cause it can detect and discriminate between normal and cancer cells due to ATP (Adenosine Triphosphate) necessity of the cell. Cancerous cells grow rapidly so it need bigger amount of ATP than normal cells.

Antioxidant compound of leaves or seeds of soursop (A. muricata Linn.) can be used to avoid free radicals so the cancer cell growth can also be prevented. However, the antioxidant capacity in leaves (L) ethanolic extract relatively higher than seeds (S).

Nonparametric Mann-Whitney analysis use to know if there is significant differences between antioxidant capacity of leaves (L) and seeds (S). The analysis result showed at Table 2. 
Table 2. Mann-Whitney Analysis.

\begin{tabular}{|l|r|}
\hline \multicolumn{2}{|c|}{ Test Statistic $^{\mathrm{b}}$} \\
\hline Mann-Whitney U & Antioxidant Capacity \\
Wilcoxon W & .000 \\
Z & 3.000 \\
Asymp. Sig. (2-tailed) & -1.549 \\
Exact Sig. [2*(1-tailed Sig.)] & .121 \\
a. Not corrected for ties. & $.333^{\mathrm{a}}$ \\
b. Grouping Variable: Extract &
\end{tabular}

Table 2 showed that Asymp. Sig. (2-tailed) value is 0,121 . This value determine if there is significant differences between two samples. If Asymp. Sig. (2tailed) value is higher than significancy value $(\alpha)$, so there are no significant differences between two samples. On the other hand, if Asimp. Sig. (2-tailed) value is lower than significant value $(\alpha)$, so there are significant differences between two samples (Trihendradi, 2007).

Asymp. Sig. (2-tailed) value in this research is 0,121 (Table 2). This number showed there are no significant differences between antioxidant capacity of leaves (L) and seeds (S) ethanolic extract. The values indicate that either soursop leaves (L) or seeds (S) ethanolic extract can be resources of natural antioxidant compound which potential to be an anticancer candidate compound. To improve that potency, it needs simple, quick, and low cost extraction method so that both leaves (L) and seeds (S) can be extracted well. The extraction method between soursop leaves (L) and seeds (S) might be different due to those different shape and texture.

\section{CONCLUSION}

Ethanolic extract of soursop (A. muricata Linn.) leaves has higher antioxidant capacity than seeds that is $85,67 \%$ and $39,01 \%$, respectively. However, there are no significant differences of the antioxidant capacity between those two samples. The higher antioxidant capacity of soursop leaves affirm its potency to be a natural anticancer candidate compound. The lower antioxidant capacity of soursop seeds may be caused by its extraction difficulties so the compound cannot be fully extracted.

\section{ACKNOWLEDGEMENT}

The authors would like to thank all the participants and partner of this research including Biology Laboratory technician of Universitas PGRI Semarang and others whom cannot mention each.

\section{REFERENCES}

Akomolafe S. F. \& O. B. Ajayi. 2015. A comparative study on antioxidant properties, proximate and mineral compositions of the peel and pulp of ripe Annona muricata (L.) fruit. International Food Research Journal 22 (6): 2381-2388.

Arifianti, L., Sukardiman, H. Studiawan, Rakhmawati, \& L. Megawati. 2014. Soursop (Annona muricata L.) seeds extract activity test to mammalian cancer cells in vitro. Jurnal Farmasi dan Ilmu Kefarmasian Indonesia. 1 (2): 63-66.

Chew, K. K., S. Y. Ng, Y. Y. Thoo, M. Z. Khoo, and W. M. A. Wan. 2011. Effect of ethanol concentration, extraction time and extraction temperature on the recovery of phenolic compounds and antioxidant capacity of Centella asiatica extracts. International Food Research Journal 18: 571-578.

Fathurrachman, D. A. 2014. The effect of solvent concentration to antioxidant capacity of soursop (Annona muricata Linn.) leaves ethanolic extract with DPPH method. Medical Faculty. UIN Syarif Hidayatullah. Jakarta.

Idrus, R. B., N. Bialangi, L. Alio. 2012. Isolation and characterization of alkaloid compound from soursop (Annona muricata Linn.) seeds. Chemistry Education Science Faculty. Universitas Negeri Gorontalo.

Limbono, S. 2013. Antioxidant Capacity of canarium nut (Canarium indicum L.) seeds ethanolic extract with DPPH (1,1-diphenyl-2-picrylhydrazyl) method. Jurnal Ilmiah Mahasiswa Universitas Surabaya 2 (2).

Nihlati, I., A. Rohman, \& T. Hertiani. 2014. Antioxidant capacity of ethanolic extract of Boesenbergia pandurata (Roxb.) Schlecth. with DPPH (1,1-difenil-2-pikrilhidrazil) method. Pharmacy Faculty. Universitas Gadjah Mada. Yogyakarta.

Prasetyorini, Moerfiah, S. Wardatun, \& Z. Rusli. 2014. Antioxidant potency of some parts of soursop Annona muricata Linn.). Penel. Gizi Makan 37 (2): 137-144.

Puspitasari, M. L., T. V. Wulansari, T. D. Widyaningsih, J. M. Maligan, dan N. I. P. Nugrahini. 2016. Antioxidant capacity of soursop (Annona muricata L.) leaves supplement and mangosteen (Garcinia mangostana L.) fruit skin: References Study. Jurnal Pangan dan Agroindustri (4) 1: 283-290.

Shekhar, T. C. \& G. Anju. 2014. Antioxidant activity by DPPH radical scavenging method of Ageratum conyzoides Linn. leaves. American Journal of Ethnomedicine. 1 (4): 244-249.

Trihendradi, C. 2007. An easy way to use SPSS 15 for descriptive, parametric, and nonparametric statistic. Penerbit Andi. Yogyakarta, pp: 127-129.

WHO. 2009. Cancers: The Problem. http://www.who.int/nmh/publications/fact_sheet_cancers_en. pdf. 